\title{
The Future of World Heritage and the Emergence of Transnational Heritage Regimes'
}

\author{
Willem J. H. WiLLEMS
}

Faculty of Archaeology, Leiden University, the Netherlands

\begin{abstract}
The World Heritage Convention of UNESCO, which celebrated its 40th anniversary in 2012, was intended to promote the preservation and enjoyment of the world's most important natural and cultural heritage. It is now fast losing credibility because of political maneuvering and the inscription of sites that do not meet requirements for reasons of prestige and tourism development. This also threatens its role as an instrument to improve heritage management. That role is increasingly taken up by international corporations and banks, and globally we may well be seeing a shift from state-based frameworks that all go back to a "European" way of dealing with heritage, a regime, to a global and transnational heritage regime. At the same time, existing infrastructure and legislation in Western countries are under scrutiny as a result of financial crisis and economic recession, and, for developing countries, the wisdom of importing Western procedures and ethics is rightly being questioned.
\end{abstract}

\section{Resumen}

La Convención del Patrimonio Mundial de la UNESCO, que celebra su cuadragésimo aniversario en 2012, tuvo como fin fomentar la conservación y el disfrute del patrimonio cultural y natural más importante del mundo. Actualmente dicha convención está perdiendo credibilidad rápidamente debido a maniobras políticas y a la inscripción de sitios que no reúnen los requisitos por cuestiones de prestigio y desarrollo del turismo. Esto también pone en riesgo su papel de instrumento para mejorar la gestión del patrimonio. Cada vez más las empresas y los bancos internacionales están asumiendo dicho papel, y a nivel mundial es posible que estemos frente a un cambio de estructuras basadas en el estado que regresan a una manera "europea" de ocuparse del patrimonio, un régimen, por un régimen del patrimonio transnacional y mundial. Al mismo tiempo la infraestructura 
y la legislación existentes en los países occidentales están bajo escrutinio como resultado de la crisis financiera y la recesión económica, y, en el caso de los países en desarrollo, la sensatez de importar procedimientos y ética occidentales se está cuestionando justamente.

\section{Résumé}

La Convention du patrimoine mondial de I'UNESCO, qui célèbre son 40e anniversaire en 2012, a pour but de promouvoir la préservation et l'appréciation du patrimoine naturel et culturel le plus important du monde. Aujourd'hui, elle perd rapidement de sa crédibilité à cause de certaines manoeuvres politiques et de l'inscription de certains sites qui ne répondent pas à ses exigences, pour des raisons de prestige et de développement du tourisme. Cela menace également son rôle d'instrument pour l'amélioration de la gestion du patrimoine. Ce rôle est de plus en plus souvent assumé par des multinationales et des banques, et il est tout à fait envisageable qu'à l'échelle mondiale nous passions un jour d'un cadre de gestion du patrimoine par l'Etat, dans la tradition « européenne », à un régime mondial et transnational. Dans un même temps, l'infrastructure et la législation existantes dans les pays occidentaux font l'objet d'examens en raison de la crise financière et de la récession économique; et dans les pays en voie de développement on se pose à juste titre la question de savoir s'il est sage d'importer des procédures et valeurs éthiques occidentales.

KEYWORDS: World Heritage, UNESCO, World Heritage Committee, archaeological heritage management, CRM, heritage regime, expertise, ICOMOS, ICAHM, World Bank, politics

In 20I 2, UNESCO celebrated the 40th anniversary of the World Heritage Convention, which has provided the impetus for a reflection on its role and future with respect to archaeological heritage management. That anniversary has been occasion for reflection (e.g., ICOMOS 20I2; Meskell 20I3; Rodwell 20I2). This paper is about archaeological World Heritage, in the sense used by UNESCO to designate the most important cultural and natural heritage on our planet. But it is also about global archaeological heritage: all the remains from the past that have survived until the present and for which excavations and other methods of archaeological research are the main sources of information. Obviously, World Heritage represents only a tiny part of global heritage, and the challenges that both are facing are sometimes similar but can sometimes be diametrically opposed.

For World Heritage archaeological sites there is often a risk of over-exploitation of tourism potential and degradation of the resource by too many visitors (Comer and Willems 20I 2). For other parts of our global archaeological heritage, such as simple prehistoric sites, the reality is that they can be uttery destroyed for precisely the opposite reason: the fact that nobody even knows they are there. Preventing that 
from happening requires many different measures and approaches, from legislation and technical measures to outreach and communication. In that sense, World Heritage has an important role to play. It functions as the tip of the iceberg that communicates the relevance of less impressive archaeological heritage resources and may alert us to their presence underground or underwater.

\section{Archaeology and the nature of heritage}

This signal role of World Heritage also illustrates an important insight about the nature of heritage. Archaeology is about the past, but archaeological heritage management is about the role of the past in the present. Heritage is perceived as relevant because it contributes to identity and often to the legitimation of power. Managing archaeological heritage, therefore, is never neutral and is always to some degree politically sensitive. The reason why a site or even an entire landscape becomes desginated as "heritage" is related to the value that is placed on it. Very often, the intangible aspects of heritage are crucial to its value. In addition, and perhaps this is in some way a result of the rapid changes in the world around us, we venerate things that have not changed. Value is connected to age and in that sense archaeological sites or finds appear even different from buildings or other stuctures or objects because their age always seems to qualify them as heritage. Quite often in the heritage literature archaeological resources and "heritage" are treated as synonyms, which is definitely not justified.

In archaeological heritage management or "cultural resource management" it is customary to conduct a (field) evaluation to determine what values are present, and not every site that is discovered necessarily has any substantial value. Of course we always need to do an evaluation to establish what values are present or, to formulate it better, to decide what values we want to ascribe given the specific context in each case. But archaeological remains that are ordinary should not automatically qualify as heritage. One of the peculiar things about heritage is that valuation is of course always subjective and determined by the background, the training, the involvement, the prejudices and preconceptions, and many other characteristics of the persons that attach the value, including their current economic interests or political goals. Therefore, heritage is always contested, and it has become established best practice that valuation should always be done in consultation with as many stakeholders as possible.

That at least is what heritage management theory says about dealing with heritage values. But the implicit subjectivity of heritage has other implications. Heritage is not the same as the past. The past is what has been; it does not exist anymore, and archaeology is the study of that past and its imperfect and partial re-creation by research of surviving material evidence in the same way as history does with written sources. Heritage, however, is about the use of the past in the present: heritage is deliberately created by ascribing value to that material evidence, in response to the needs or desires of stakeholders. As Tunbridge and Ashworth (I996:6) have 
described the process of creating heritage: "The present selects an inheritance from an imagined past for current use and decides what should be passed on as useful to an imagined future." Heritage is thus very much a product of its time that can be used in contradicting and opposing ways. Of course heritage can unite people through a process of recreating a common past, but at the same time it can be very divisive: if something is "our" heritage, "they" are excluded, and heritage can become the source of conflict and violence. A good illustration is the recent international conflict between Thailand and Cambodia about their Khmer heritage embodied in the Preah Vihear Temple that was listed as a World Heritage Site in 2008 (Williams 20II).

This point leads to a further implication of the nature of heritage, especially where it is used by political entities such as states to legitimize their right to exercise power. It is no coincidence that the concept of national heritage was invented around the turn of the nineteenth century in Europe; this was a direct consequence of the political restructuring of post-Napoleonic Europe, the formation of nation states, and the need to develop a "national identity." The past is an essential component in that process, and it is significant that the concept of "national antiquities" was invented in this period and was rapidly applied widely all over early nineteenth century Europe.

Of course there was nothing new, even then, in the purposeful use of the past to establish the right to rule. That was already done by Babylonian kings and Egyptian pharaohs. The first heritage legislation in Europe was enacted in Sweden in I666. But it was only around I 800, at the end of the European Enlightenment age, that archaeology first developed as an academic discipline and that there came a more systematic attention to heritage conservation and protection. This was the first time a system - referred to here as a heritage regime-was created in Europe and it has been dominant in the world for two centuries.

An interesting phenomenon from the nineteenth and early twentieth century is that heritage resources also became important in the process of Western colonial expansion. Heritage became especially relevant as part of a colonial project that sought to explain and justify European dominance in terms of a Social Darwinian logic, with colonized peoples at lower stages and European civilization at the top. Although the local context was probably of little political interest, there were quite important efforts to inventory, select, interpret, and preserve heritage resources in European colonies. In many cases, these were introduced significantly earlier than in the homeland. Examples are the Archaeological Survey of India established in I 86I, the creation of the Egyptian Antiquities Service in I 858 and of the Committee for archaeological investigation in the Dutch Indies in I90I, or the Bushmen Relics Act in South Africa from I9I I.

With increasing legal regulation, a number of important questions had to be addressed that are still very relevant today: who owns heritage, who decides, and who manages? In practice, the answer has primarily been "the sovereign nation." Normally, legal systems establish controls at the level where cultural autonomy 
lies, so there is a difference between centralized countries and federal states. In reality, of course, there is always someone that exercises control on behalf of the nation, and heritage always tends to be controlled by and managed for the dominant social elite in a society through the medium of experts. So the European heritage regime mentioned above, consists of two main elements: sovereignty and expertise.

It is only very recently that changes are being made to somewhat relinquish this control by experts to empower, for example, local populations and to acknowledge them as stakeholders. This is a result of a long struggle that has its roots in AngloSaxon settler countries in North America and Australia. In the rest of the world colonies have-broadly speaking - been given back to the indigenous populations. In settler countries the native populations have been excluded from their own heritage for a long time. Their interests were being ignored or overridden, and only in the last two decades have they been recognized as stakeholders with legal rights.

In most of Europe, Asia, and Africa, however, we are our own indigenes, though that does not mean there are no disenfranchised local groups. In the same way as natives were ignored in North America, so were for example local villagers ignored in decisions about heritage in Europe. It is quite probable that the conscious involvement of local stakeholders in modern heritage resource management, and also the development of forms of community archaeology, where the local population participates in archaeological work, is to a large extent the result of a change induced by the regard and respect for other peoples' stakes in heritage resources (Willems 2009).

It is surely no coincidence that globally this started in countries with systems of Anglo-Saxon common law, where society is self-regulating, as opposed to the Roman law tradition where much depends on the State that regulates society. The latter system is more likely to adhere longer to exclusive stewardship of heritage resources to formal representatives of the state and asymmetrical power relations. This may in part explain striking differences in the role of native peoples in heritage management between most of Latin America and North America.

\section{Global challenges and the emergence of a transnational heritage regime}

There are of course good reasons for states to establish legal controls over their national heritage or at least to regulate the way in which the heritage that is present in their territory is dealt with. But there is also an international level of regulatory mechanisms for heritage resources in the form of a variety of treaties and charters. The most widely accepted is the World Heritage Convention, ratified by almost all countries in the world (I90 states). The treaty defines cultural heritage that has universal value, including archaeological monuments and sites. But these World Heritage "properties," as they are called, are not the only ones for which the Convention is relevant. It is also quite important for the management of all archaeological sites in the territory of States Parties. 
This is because the Convention has Article 5, which-even though not strongly worded-says that a State Party that signs the Convention should also develop and implement a policy for heritage management. This article, therefore, contains the formal importance and relevance of World Heritage for global heritage, and for all the less spectacular sites that are mostly buried and unknown. In developing countries, Article 5 can be an important stepping-stone to improve and develop a system for heritage management, to provide some level of protection for archaeological sites. This is further elaborated in the 1972 UNESCO Recommendation concerning the Protection, at National Level, of the Cultural and Natural Heritage.

Although it has wider implications, the main purpose of the Convention is to identify, inscribe, and thereby ensure the survival of the most important heritage assets in the world, those that are of so-called "outstanding universal value." Given the wealth of literature on the subject (Jokilehto and Cameron 2008; Labadi 20I3) it is not necessary here to go into the details of this concept and criteria for it. It is, however, useful to consider how nominated properties are being evaluated.

ICOMOS is responsible for the evaluation of all nominations of cultural sites against the criteria laid down by the World Heritage Committee. Its advice to the committee is provided through experts, organized in international committees, in the specific type of property and the universal value concerned. For archaeological sites, the experts are mostly members of the International Committee for Archaeological Heritage Management (ICAHM), or the International Committee on the Underwater Heritage (ICUCH), but also academic and other specialists are consulted. Although ICAHM is not an independent organization by itself, it is the only archaeological organization at a global level that is entirely devoted to archaeological heritage management. And although ICAHM is associated with World Heritage, most of its functions are relevant for global archaeological heritage. It is concerned with developing standards and constitutes a large network of experts.

One of the global challenges for archaeology is to bring archaeological heritage management in all parts of the world to a higher level. Many countries around the world are still quite underdeveloped. At the same time, their natural resources are being exploited at an unprecedented scale by international companies which nowadays are not only from Western countries in North America and Europe but increasingly also from emerging international powers and rapid growth economies such as India, Brazil, and China. Demand and consumption patterns in some parts of the world are imposing a very big burden elsewhere. The result of this development is that the cultural heritage in these developing countries is in grave danger. Very large scale exploitation of resources, a real need for the income that those natural resources may provide for a country, and a lack of legislation concerning impact assessments and protection of sites may produce catastrophic results.

A European example is Rosia Montana in Romania, a mountain with gold deposits, that was already mined under the Roman Empire in the second century AD. The Roman period mining town and galleries are preserved and represent a unique 
heritage asset. At the same time, the Romanian state needs the income from the mining. For a broad overview of the issues, see Vulpe et al. (20II). In this case, it is quite clear that from a culture historical perspective, the values and significance of the complex are quite considerable. In fact, some people would even like to propose this site as World Heritage, although this desire is of course strongly motivated by the desire to protect the archaeological heritage here or to oppose the mining for other reasons such as environmental concerns. The Romanian government has not put the site on its tentative list and it seems pretty obvious that it will never do so. The central question now has become to consider-in the face of clear and strong economic pressures-what decisions for preservation are appropriate and realistic? There are five key questions that should be asked in a situation like this:

I. What are the values and significance of the site?

2. Have these values been established in consultation with as wide a range of stakeholders as possible?

3. In the face of clear economic pressures, what decisions for preservation, conservation, and interpretation are appropriate and realistic?

4. Are there adequate heritage management policies for implementing such decisions and is there a track record for the proper implementation of these policies?

5. Are the standards of work associated with the implementation of the heritage management policies appropriate?

In the case of Rosia Montana, it is clear that the value is quite high: research has been thorough, and this is truly an exceptional site (Vulpe et al. 20I I). It is also true that extensive processes of consultation have taken place, though perhaps not always from a benevolent perspective. Nevertheless, the second question can be answered positively. Also, it is certainly true that Romania has adequate heritage management policies - data on their implementation are less easy to come byand the standards of work in Romanian archaeology are state of the art. There is, however, both within ICOMOS and in Romania, an ethical debate among the archaeological heritage managers as to whether ICOMOS should be allowed to participate in the third question. Some appear to consider it improper for ICOMOS to be involved in such decision making and want to keep high moral principles. Others accept the need for mitigation and compromise and believe it is necessary to participate in the debate in order to obtain the best results for the cultural heritage. It is important to recall at this point that the different opinions concerning the role of values discussed above, creates a division here too. If one defines the value of heritage as subjective and contextual instead of objective and intrinsic, then one is of course more open to debate on the future of important heritage assets in the face of other important issues.

In various arenas, this debate is still ongoing and within ICOMOS, besides being a struggle between viewpoints, it also has many elements of a power struggle. ${ }^{2}$ An important aspect of this is the willingness among heritage managers, or the lack 
thereof, to cooperate with international business and global players in development, such as the World Bank. Heritage managers, for the most part, continue to think in traditional models, whereby heritage is primarily tied to national, state-based systems of control and management: this is the European heritage regime referred to above. Also the World Heritage Convention is completely based on the primacy of the sovereign nation: only a national government can propose a site and nations not recognized as sovereign states - such as Taiwan, Somaliland, or, until recently, Palestine-are excluded from membership. In the globalizing world of today, however, the international private sector is becoming increasingly important and is supplementing such state-based national frameworks (that ultimately all go back to the European heritage regime) with what can be called global and transnational heritage regimes.

A good illustration of this emerging trend is a new book that was published recently by Rio Tinto, one of the largest mining consortia in the world (Bradshaw et al. 20II). It was produced by Rio Tinto in cooperation with an Australian academic center, assisted by an international review panel comprising a variety of experts in cultural heritage. It provides admirable and state of the art guidance on dealing with cultural heritage issues in practice. This goes beyond anything produced so far (cf. King 20I2), though it is not new in the sense that in recent years various international organizations have provided guidance. An example are the policies for cultural heritage assessments established by the World Bank and the International Finance Corporation to ensure that high quality assessments are undertaken for projects they finance, no matter where in the world these take place (cf. International Finance Corporation 20I2; World Bank 2013). What one sees internationally is that new frameworks are generated by organizations such as Rio Tinto, Shell or Exxon, the World Bank, the IFC, or various development banks providing guidance for their own global operations, and of course this is not done solely for altruistic motives.

The basic cornerstone for protecting cultural heritage is provided by the legal frameworks that exist at the national and international level, as well as the best practices contained in (inter)national charters. In addition to those, there is the motive of corporate social responsibility (CSR) as such, and voluntary self-regulation makes an international business or other organization look good. But, at the same time, such "best practices" are also a business strategy. In his foreword to the guide, Rio Tinto CEO Sam Walsh explicitly states that there is a business motive for respecting and protecting cultural heritage: "We do this because it is the right thing to do and because there is a strong business case for doing so" (Bradshaw et al. 20II:6). It is quite clear that many international organizations have realized that if they deal with heritage in a way that is seen as appropriate by local people and professionals, this is an effective investment strategy because good relations pay off in the long run. At the same time, it is also a clever risk reduction strategy because compliance diminishes the risk of claims, local unrest, or government interference that may hamper business operations and diminish profit. 
It can surely be concluded, therefore, that international businesses, even if only doing it out of enlightened self-interest, can be useful partners in heritage management. Of course it is true that certainly not all international businesses have realized that oldfashioned capitalist style operations may not be in their best interest, and some appear to be in the process of change. It is quite clear that, for example, the strategies for dealing with the archaeological heritage by mining operations at Rosia Montana have changed over time (Vulpe et al. 20II). The same no doubt applies to Rio Tinto. While the guidebook is so up to date that it even considers the issue of listening to dissident voices in communities - which in the real world are never truly homogeneous - it does not consider that, of course, Rio Tinto itself is also not a homogeneous entity, and there is certainly dissident behavior of partner mines. There are examples where the company operates in an exemplary manner, such as in Mongolia, ${ }^{3}$ and there are various cases where operations have raised questions, such as in Papua New Guinea (Taylor 20II), the Kakadu National Park in Australia (Aplin 2004), and recently the case of Apache Leap in the United States, in Arizona (Malakoff 20II).

A possibly hopeful sign is the Gas and Preservation Partnership (GAPP) intitiative, an American not-for-profit organization that works with the energy industry as well as the heritage industry "to identify and properly manage historic and cultural resources while encouraging efficient exploration and development of energy reserves." 4 A conference in March 20I4 in Pittsburgh was apparently a success. Its objectives were to educate the energy industry about the social and economic importance and methodologies of cultural resource preservation and vice versa, to educate the preservation community about the economic and geopolitical importance and methodologies of energy development. Significantly, the third objective was to develop the business case for working together to develop voluntary practices that advance energy exploration while protecting the most important cultural resources. What this means in practice remains to be shown, but at least there is dialogue instead of confrontation.

This is also true for the international financial institutions that finance infrastructure and industrial development. The World Bank's procedure for physical cultural heritage was revised in 2013 and in the summer of 2014 a meeting is planned by the Society for American Archaeology (SAA) to discuss the cultural heritage management policies and practices of development banks in Latin America. The meeting grew out of the recognized need to improve and strengthen cultural heritage management compliance with bank policies. The meeting is expected to bring together representatives of the World Bank, the International Finance Corporation, and the Inter-American Development Bank, national authorities, and heritage practitioners. Any results will be known when this paper appears in print.

There are a number of comments that can be made about these recent events. First of all, it is a major step forward that increasingly such dialogues are being established. They do help, even when there is no doubt that if a development bank or a big international company changes its policies, not all of its parts may comply equally well. There are bound to be control issues in big conglomerates, and it may take time 
before new policies are fully implemented. A second remark is that, in part, these cases - and the losses they caused, both in the sense of heritage losses and economic losses - are probably what has led Rio Tinto to design a corporate heritage policy: organizations can and do learn from past mistakes. It should also be mentioned that statebased systems are dependent on political decision making that can be extremely whimsical at times and susceptible to short-term change, as heritage managers in various countries around the world are finding out right now, in a time of economic crisis. So, political decision making by states does not always yield results that are necessarily superior to economic decision making by companies.

Thirdly, one area where the national-level systems, for the time being, appear to be better equipped is the organization of quality control. While the intent behind the international guidance and standards that have been developed is laudable, there remain problems even when they are formally complied with because there is no firm and broadly accepted framework to evaluate results. The quality of much work or studies depends on professional ethics alone and is not being reviewed nor is the competence of the professionals involved assessed in any way. Clearly, there could be a task here for organizations such as the UK Institute For Archaeologists (IFA) or the North American Register of Professional Archaeologists (RPA). Moreover, there is a need to develop standards and criteria to evaluate the quality of studies commissioned by international companies and financial institutions. International organizations such as ICOMOS-ICAHM might include this in their standard-setting work.

Finally, there are also critiques from those that do not consider heritage values to be contextual and negotiable in any way, or that have radical views of society that are incompatible with attempts to introduce corporate social responsibility. These types of critiques obviously cannot be easily debated: they can be respected, but for a debate at least a certain measure of common ground would be required on basic principles, before it becomes fruitful.

Debatable or not, it seems that we are currently in a development whereby the predominant European heritage regime is being supplemented if not gradually superseded by a new transnational heritage regime. This is a regime that combines ethical frameworks from global organizations-both private corporations and public bodies - and that does not rely solely on experts as stewards or caretakers, but actively seeks to empower local populations. This is a trend that is connected to recent proposals for a human rights approach to cultural heritage (Blake 20I I; Hodder 20I0) and of which the international community of heritage experts is only just becoming aware, so most of its consequences still need to be examined.

One such consequence that constitutes a global challenge resulting from the effects of development are the effects of uncritical export of Western ethical principles. A good example of this is the principle of preservation in situ. In much heritage legislation and ethical codes there are principles that imply a "presumption in favor" of preserving sites in situ, on the assumption that they are better left untouched as far as possible. In Western heritage bureaucracies this has become almost a dogma, even 
though it relies in part on doubtful assumptions. Also, it becomes increasingly common in the practice of heritage management to define all sorts of damaging impacts that are allowed to take place on preserved sites, or to preserve only parts, just to save money and with virtually no chance of survival until a very unlikely future research excavation (cf. Willems 20I2).

That point is even more true in third world countries, where the number of positions in academic archaeology is usually quite limited: just a few people at the national level at best. If you mirror cultural resource management strategies after Western practices there, it implies that site avoidance and mitigation of construction impacts on cultural heritage become the primary goals. As a highly interesting recent study has shown (MacEachern 20I0), excavation for research purposes - to actually learn something about the cultural history of an area-or for training purposes, are then seen as an illegitimate use of client funds or as unacceptable acts of destruction of archaeological resources. That is very obviously wrong. In a third world context, capacity building and taking advantage of properly resourced research opportunities, should take precedence over maintaining principles such as preservation in situ. If we do not grab the opportunity when it presents itself, we will lose the knowledge and what it can be used for, and also the sites and the rare chance to properly train and educate local colleagues. The implication of this is that the emerging transnational heritage regime discussed here, is, in reality, certainly not free from Western dogmas.

\section{World heritage in trouble}

Not being free from Western dogmas is all the more true for the World Heritage regime, of course, if indeed we can call it that, because the Convention is in fact mostly European in origin and content. It is also quite unbalanced, and UNESCO has developed a strategy to deal with these imbalances (UNESCO 20I4). Differences between various regions is just one of them. Another one-that surely is of equal importance - is the fact that some categories such as archaeological sites and cultural landscapes are seriously underrepresented in comparison with built heritage such as historic towns. Attempts to remedy this situation are ongoing (Cleere 20II; Rodwell 20I2; Willems and Comer 20II) but appear to meet with limited success (Steiner and Frey 20II).

One cause of this lack of success is the fact that the nomination process is so complicated, scrupulous, and precise. In the end, however, it depends on the decisions of the World Heritage Committee, which consists of 2I elected Member States. The system was set up so that the national representatives in the committee could be advised by heritage conservation experts, but member states have become increasingly aware of the tourism potential of World Heritage sites. In addition, having World Heritage sites is increasingly seen as a contribution to national prestige. This is why nearly all countries in the world are party to the World Heritage Convention nowadays. This development has caused the composition and also the 
decision making of the Committee to become increasingly political (Jokilehto 20I I; Meskell 20I 2; Meskell et al. in press). For many years now political representatives in national delegations have shown increasing disregard for expert advice. Increasingly, the Committee has chosen to inscribe properties that did not have the proper protective structure, effective management plans, etc. This despite the evidence that when such sites are inscribed, they often become problem properties that require continuous attention.

The example of the temple at the border between Cambodia and Thailand, is a case in point. By itself Preah Vihear qualifies as a World Heritage site, but in 2007 it was initially rejected because it lies in a long-disputed border zone, and there were serious problems with establishing a buffer zone and a good management plan (Williams 20I I). In 2008, however, the Committee decided to inscribe the site anyway, against all advice and against the explicit wishes of the Thai government. This unfortunate decision has since then led to an actual military conflict. A better illustration of the way in which the World Heritage process has derailed is hardly imaginable, but there are by now many other examples of politically-inspired decisions, even though not all have such catastrophic consequences (see Meskell 20I2). The composition of the committee has changed three times since 2008, and during subsequent sessions of the World Heritage Committee in 2010 and later, its members have continued on this path and have shown an extreme disregard of expert advice by adopting such radically political decisions that the credibility of the list is likely to become seriously compromised. In 44 percent of the cases the Committee proceeded to inscribe sites on the World Heritage List despite the judgment of the advisory bodies that these sites had not met the requirements for inscription. ${ }^{5}$

Of course there is more to this than meets the eye. First, there is a clash between different visions on the purpose of the World Heritage List. World Heritage sites are being defined by more or less objective "values" and a process that intends to be impartial but which at the same time results in preferential treatment for richer and more developed countries and for monumental built heritage. Second, there is also political powerplay going on. When the composition of the committee is considered, it is clear that although from time to time they have to vacate their seat because their term is up, the BRIC countries are constantly running for re-election. If one looks at a map of World Heritage density at the UNESCO website it is clear that China has already reached the level of Spain and Italy and the others-Brazil, Russia, and India - are apparently catching up fast.

That by itself would be entirely justified for the right reasons: places with outstanding and universal values are present in all BRIC countries. But powerplay in the Committee for political reasons can be quite dangerous. A good illustration of this unwelcome trend is the way in which the Committee chose to ignore the joint advice of ICOMOS and the World Heritage Centre of UNESCO regarding the inclusion of highly threatened sites in the List of the World Heritage Sites in Danger. In spite of the fact that the Danger List is only a tool to rally international 
cooperation and support and not a punishment, the advice to include highly threatened sites in the World Heritage in Danger List has been mostly disregarded. This illustrates the purely political nature of decisions: it was intended as a useful tool, but it works like a reprimand. As a headline in The Economist from July I4, 20 I 2 concisely summarized it: UNESCO is better at naming enemies than finding friends (The Economist 20I2).

UNESCO has run into even more problems now that Palestine has been admitted as a member and of course wants to nominate its own sites. This alone should not have been a problem and there appear to be a number of potential World Heritage sites in Palestine. But, at the same time, it is clear that given the whole political minefield surrounding this, a nomination such as that of Bethlehem, inscribed at the 36th session of the Committee in Russia in 20I2, is being used by all concerned to make political statements.

Of course it is true that if heritage is about the role of the past in the present, about identity, and about legitimization, it will always be political to some degree. By its very nature it cannot escape this fate. Also there is nothing inherently wrong with Western perspectives - which have led to a seriously unbalanced World Heritage List-now being supplemented or replaced by other viewpoints. It will only enrich the whole concept of World Heritage when it becomes part of a transnational instead of a European heritage regime as outlined above. But at the same time, there can be no doubt that the credibility of the World Heritage List will erode rapidly if the new viewpoints are largely political and reflect narrow nationalistic or tourism agendas (Meskell 2013). In addition, the list has also grown quite large and the number of inscriptions has just passed I, 000 at the 38 th session of the Committee in Qatar in June 20I4.

The World Heritage List has been a great tool to promote the varying interests and uses of heritage and for global cooperation and mutual support, as well as a source for improvement of heritage management practices at the national level-but it may well lose its credibility and become ineffective. Even its effect on tourism will probably wear off soon enough, and if that happens, global heritage will suffer the consequences, unless, of course, the World Heritage Committee somehow decides to depoliticize its decision making. Since the 2013 session in Cambodia the composition of the World Heritage Committee offered hope for change (its current members are Algeria, Colombia, Croatia, Finland, Germany, India, Jamaica, Japan, Kazakhstan, Lebanon, Malaysia, Peru, Philippines, Poland, Portugal, Qatar, Republic of Korea, Senegal, Serbia, Turkey, and Vietnam), but the 38th session in Qatar in June 20I4-while on the surface discussions were much more polite-was more political and less receptive to professional advice than ever: more than half were rejected or disregarded.

In a recent report, some of the States Parties have put forward a number of suggestions that could actually achieve such a depoliticization. ${ }^{6}$ These include proposals such as a more frequent rotation of States that are member of the Committee, the commitment of States not to introduce a national nomination file in the course of 
a term of office in the Committee, and the idea that experts "qualified in the field of cultural and natural heritage" should once again feature prominently in delegations. It is proposed that States seeking election to the Committee should have experts who act independently, and it is even recommended that States Parties are represented by these experts. A preference to elect countries on the Committee that have an action program and priorities in line with the Global Strategy of UNESCO that seeks to balance the World Heritage List is another recommendation that seems obvious. In addition, there are the improvements proposed by UNESCO to create a more cooperative nomination process (Araoz 20II; Meskell 20I3; Rao 20I0).

It is to be hoped that at least some of these proposals will actually be adopted by the Committee, so that despite the inherently political character of its work, the committee brings back the role of expertise. That is crucial, especially if this will be non-Western expertise. This is one item that is lacking in the recommendations so far, which appear to assume that there is only one kind of expertise that is somehow universal. Without such varied expertise, the World Heritage List will never become balanced, and it most certainly will not become more credible. It will fast become obsolete.

\section{References}

Aplin, Graeme 2004 Kakadu National Park World Heritage Site: Deconstructing the Debate, I997-2003. Australian Geographical Studies 42(2): I 52-I74.

Araoz, Gustavo 20I I Preserving Heritage Places under a new Paradigm. Journal of Cultural Heritage Management and Sustainable Development I(I):55-60.

Blake, Janet 20I I Taking a Human Rights Approach to Cultural Heritage Protection. Heritage \& Society 4 (2): $199-238$.

Bradshaw, Elisabeth, Katie Bryant, and Tamar Cohen (editors) 20I I Why Cultural Heritage Matters. A Resource Guide for Integrating Cultural Heritage Management into Communities Work at Rio Tinto. Rio Tinto, Melbourne/London.

Choay, Françoise 200I [I992] The Invention of the Historic Monument. Translated by L. M. O'Connell. Cambridge University Press, Cambridge.

Cleere, Henry 20 I I The I 972 UNESCO World Heritage Convention. A Success or a Failure? Heritage \& Society 4(2):I73-I 86 .

Comer, Douglas and Willem J. H. Willems 2012 Tourism and Archaeological Heritage. Driver to development or Destruction? In Heritage, a Driver of Development. Proceedings of the 17th ICOMOS General Assembly Symposium, edited by C. Gottfried, and S. Hidalgo Sánchez, pp. 499-5 I I. ICOMOS, Paris.

The Economist 2012 Living Treasure. UNESCO is Better at Naming Enemies than Finding Friends. Economist, July I4th, 20I 2. Electronic document, http://www.economist.com/node/2I 558560 ?fsrc=scn/tw/te/ar/living treasure, accessed April 20, 2013.

Hodder, Ian 2010 Cultural Heritage Rights: From Ownership and Descent to Justice and Well-being. Anthropological Quarterly 83(4):86I-882.

ICOMOS $20 \mathrm{I} 2$ The World Heritage Convention: Thinking Ahead-Ideas, Proposals and Considerations from ICOMOS for Exploration. September 2012. ICOMOS, Paris.

International Finance Corporation 20I2 IFC Performance Standards on Environmental and Social Sustainability. International Finance Corporation, Washington.

Jokilehto, Jukka 20I I World Heritage: Observations on Decisions Related to Cultural Heritage. Journal of Cultural Heritage Management and Sustainable Development I(I):6I-74. 
Jokilehto, Jukka and Christina Cameron 2008 The World Heritage List: what is OUV?: Defining the Outstanding Universal Value of Cultural World Heritage Properties. Bäßler Verlag, Berlin.

King, Thomas F. 2012 Rio Tinto Talks the Talk. The Historic Environment: Policy and Practice 3(2):166-I69. Labadi, Sophia 20I3 UNESCO. Cultural Heritage and Outstanding Universal Value. AltaMira Press, Walnut Creek, California.

MacEachern, Scott 20Io Seeing like an Oil Company's CRM Programme: Exxon and Archaeology on the Chad Export Project. Journal of Social Archaeology Io(3):347-366.

Malakoff, David 20I I Breaking News: Archaeology Groups Oppose Proposed Arizona Land Swap. Science. Electronic document, http://news.sciencemag.org/scienceinsider/20I I/Io/breaking-news-archeology-groups. html? rss=I, accessed May I2, 20 I 2.

Meskell, Lynn 2012 The Rush to Inscribe: Reflections on the $35^{\text {th }}$ Session of the World Heritage Committee UNESCO Paris, 20I I. Journal of Field Archaeology 37(2):I45-I 5 I.

Meskell, Lynn 20I3 UNESCO's World Heritage Convention at 40. Challenging the Economic and Political Order of International Heritage Conservation. Current Anthropology 54(4):483-494.

Meskell, Lynn, C. Liuzza, E. Bertacchini, and D. Saccone 20I4 Multilateralism and UNESCO World Heritage: Decision Making, States Parties and Political Processes. International Journal of Heritage Studies 20: I-I8.

Petzet, Michael 2009 International Principles of Preservation. Bäßler Verlag, Berlin.

Rao, Kishore 20 Iо A New Paradigm for the Identification, Nomination and Inscription of Properties on the World Heritage List. International Journal of Heritage Studies I6(3):I6I-I 72.

Rodwell, Dennis 2012 The UNESCO World Heritage Convention, I972-2012: Reflections and Direction. The Historic Environment 3(I):64-85.

Steiner, Lasse and Bruno S. Frey $20 \mathrm{I}$ I Correcting the Imbalance of the World Heritage List: Did the UNESCO Strategy Work? (Working paper series I4). Department of Economics, Zürich.

Taylor, Nicholas 20I I High Risk Areas, Resources and Sustainability. In Evolutions in Sustainable Investing: Strategies, Funds and Thought Leadership, edited by Cary Krosinsky, Nick Robins, and Stephen Viederman, pp. 329-344. Wiley Publishers, New York.

Tunbridge, John E., and Gregory J. Ashworth 1996 Dissonant Heritage: The Management of the Past as a Resource in Conflict. Wiley Publishers, New York.

UNESCO $20{ }_{4}$ Global Strategy. UNESCO, Paris. Electronic document, http://whc.unesco.org/en/globalstrategy, accessed April 9, 2014.

Vulpe, Alexandru, Răzvan Theodorescu, Ioan Pop, Ioan Opriă, Nicolae Gudea, Augustin Ioan, Vasile Moga, Alexandru Diaconescu, and Florin Anghel 20I I The cultural heritage at Roăia Montană. Current Situation and Real Perspectives. History Institute "Nicolae Iorga," Bucharest.

Willems, Willem J. H. 2009 European and World Archaeologies. World Archaeology 4I (4):649-658.

Willems, Willem J. H. 20 I 2 Problems with Preservation in situ. Analecta Praehistorica Leidensia 43/44, I-8.

Willems, Willem J. H., and Douglas Comer 20I I Africa, Archaeology and World Heritage. Conservation and Management of Archaeological Sites I3 (2-3): I60-I73.

Williams, Tim 2or I The Curious Tale of Preah Vihear: The Process and Value of World Heritage Nomination. Conservation and Management of Archaeological Sites I3(I):I-7.

World Bank 20I3 Operational Manual 4.11-Physical Cultural Resources. Electronic document, http://web. worldbank.org/WBSITE/EXTERNAL/PROJECTS/EXTPOLICIES/EXTOPMANUAL/o,,contentMDK :20970737 menuPK:6470I 637 pagePK:64709096 piPK:64709 I08 theSitePK:502 I 84,00.html, accessed July 4, 20I4.

\section{Notes}

I An early version of this lecture was originally presented as a keynote on Menorca in April 2012 at the "First International Conference on Best

Practices in World Heritage: Archaeology.” The meeting was organized by the Universidad Complutense de Madrid in cooperation with the 
ICOMOS International Committee on Archaeological Heritage Management.

2 On the theoretical perspectives, see Labadi (20I3), Chapter I. The struggle has surfaced for example in the belligerent introductory chapter to Petzet (2009)-entitled "Conservation or managing change?"-in which he deals with what he calls an "Australian" heritage philosophy and shows himself to be suffering severely from what the French architectural historian Françoise Choay (200I) has termed the "Noah complex," the cult of historic heritage. Michael Petzet is the German past president of ICOMOS and the book was published in the ICOMOS series with German funds but without consulting ICOMOS. In June 2010 the organization issued a formal Disclaimer- "International Principles of
Preservation." See also Araoz (20II) and Rodwell (20I2).

3 See http://www.ot.mn/en/communities/landcultural-resources, accessed May 3I, 20I2. It refers to a comprehensive cultural heritage program for the South Gobi desert that will be affected by the Oyu Tolgoi mines.

4 See http://gasandpreservation.org/, accessed April 9, 2014.

5 In 20I4, it had risen to well over 50 percent. A gripping analysis of these processes that documents much of what is said here in greater detail, is being published by Meskell et al. (in press).

6 "Non-paper" of the Benelux delegation, provided by Dr. Koos Somer, Ministry of Education Culture and Science, the Netherlands. 